\title{
The Process of Albania Enlargement of the European Union, the Transition, Reforms and Changes in Public and Private Sector of Economy
}

\author{
Prof. Assoc. Dr. Alba Dumı \\ Dean of Graduated School, Ismail Qemali" Vlore University, Albania \\ Management Department, Economy Faculty, Tirana University, Albania \\ Email: besi.alba@yahoo.com \\ Ma. Arlinda Velaj \\ Management Department, Economy Faculty, Tirana University, Albania \\ Email: arlinda velaj@yahoo.com \\ Ma. Estela Çobo \\ Management Department, Economy Faculty, Tirana University, Albania \\ Email: estelacobo@yahoo.com
}

\section{Doi:10.5901/mjss.2013.v4n9p689}

\section{Abstract}

Challenges in identifying the appropriate electoral system and institutional arrangements to achieve inclusiveness require developing an adequate knowledge of the local electorate and identifying a combination of electoral system and affirmative action which best suits the structural as well as institutional context. The capacity of public administration was weak; the system, stemming from a party focused environment, was highly politicized. Corruption was pervasive in every facet of the public sector. Citizens feared public administration and did not trust it to provide even the most basic services in a fair or impartial way. The financial collapse in 1997 was a watershed event in Albania's transition from its communist past. It highlighted the problems of Albania's economic governance capacity and, from an administrative standpoint, reaffirmed and highlighted the inefficacy of a public administration, unable to enforce its laws and regulations. As the public's confidence in Albanian1 institutions had been significantly eroded by the recent events, restoring the public's trust in the government became the main priority of the government. In order to achieve this objective the capacity of the public administration needed to be dramatically strengthened.2 The donors concurred with this assessment. IDA, starting with the 1998 CAS, considered governance and institution building as one of the central planks of its intervention and identified the need to adopt and implement reforms to build an accountable and transparent state as the most important challenge facing the Government of Albania. Over the next several years, the Albanian Government, in partnership with donors, emphasized institutional reform and capacity building and developed a comprehensive strategy to strengthen the public institutions for more effective governance. 3

Keywords: Administrative system, implementing financial reforms, accountable \& transparent financial public goals, administration strength micro credit lines.

\section{Introduction}

This study empirically examines the impact of debt management policies on borrowing costs incurred by state governments when issuing debt in the municipal bond market. Based on positive political theory and the benefit principle of taxation, it is proposed that states that adhere to best practice debt management policies transmit signals to the credit ratings, investment community and taxpayers that the government should meet its obligations in a timely manner, resulting in lower debt costs. This was my entire point with temporarily nationalizing the banks. Banks are not going to

\footnotetext{
${ }_{1}^{1}$ The Project Development, Project Appraisal Document (PAD) (Report No. 2000, page 59-ALB)

${ }^{2}$ Structural Adjustment Credit (SAC \& ICR Ministry of finance, Supreme Audit Institute ,year 2009, 2010

3 Ida \& CAS report for developing in Albania
} 
lend until the bad assets are off their books. Someone is going to pay. If we nationalized, at least we shared on the upside potential. "Three Basic Principles: Using $\$ 75$ to $\$ 100$ billion in TARP capital and capital from private investors, the Public-Private Investment Program will generate $\$ 500$ billion in purchasing power to buy legacy assets - with the potential to expand to $\$ 1$ trillion over time. The Public-Private Investment Program will be designed around three basic principles: Maximizing the Impact of Each Taxpayer Dollar: First, by using government financing in partnership with the FDIC and Federal Reserve and co-investment with private sector investors, substantial purchasing power will be created, making the most of taxpayer resources.( Anthony, R. N. and Dearden 1980)

\subsection{The importance of this study, the overview of management policies}

As a result (USA political debt and reforming policies) of a multi-block multivariate regression model the implication of adhering to debt policies aimed at promoting transparency results in a borrowing cost savings in terms of true interest cost (TIC). However a comprehensive debt policy is not a significant indicator of borrowing costs. These results suggest a product of a pull-push process between the economic forces of the bond market on one hand and politics on the other, pulling the administrative function toward efficiency in the former and democratic values of responsiveness and transparency in the latter.

The problem lies in policies that respond to the bond market but virtually exclude any other community interest in policy making. It is recommended that openness in government and allowing taxpayers to understand government services are essential goals in ensuring responsible citizen oversight and providing taxpayers the opportunity to be less likely to propose restrictive initiatives or force dramatic political or management changes through the electoral process or bond referenda

The EU remains Albania's main trading partner, providing $64.1 \%$ of Albania's imports and receiving $70.2 \%$ of exports as of September 2010. Trade with Italy and Greece, although steadily declining since 2008, continues to represent the largest share of EU trade, with a combined $40.8 \%$ of imports and $56.4 \%$ of exports as of September 2010. Other major trading partners include Turkey, China, and Germany. (Anthony, R. N. and Dearden 1980)

The impact of CEFTA in Albania's trade with member countries has been small. ${ }^{4}$ Albanian case study during this on the outcome of electoral systems and local politics and how more inclusive systems of local governance can be developed. It was emphasis that the choice of electoral system can create opportunities for greater representation of women, ethnic minorities, the poor and other disadvantaged groups in local government. Structural as well as institutional factors pose major challenges faced in achieving this outcome. Affirmative action was not seen as a viable long-term solution for achieving increased representation of these groups.

\subsubsection{Albanian transition and needs for changes in public sectors.}

Albania Government worked with donors on the public financial management agenda by strengthening core public financial management units (Ministry of Finance, Supreme Audit Institute, Procurement Directorate within the Office of the Prime Minister) as well as the financial management units within each line agency (e.g., budget departments within line Ministries). On matters relating to public sector human resource management, the reform strategy envisaged addressing this issue in two major stages: civil service reform and broader public sector human resource management reform. During the stage, the reforms aimed to create the managerial and professional nucleus required to lead any serious efforts to improve the accountability and performance of public institutions.

\section{Literature Review and Hypotheses}

\subsection{The impact, performance and cultural development in Albania and Balkan.}

After the fall of socialism, Albania largely succeeded in providing targeted assistance to the poor when compared with other low-income countries (Alderman 2002). And, despite strong turmoil, Albania has found its way to becoming a democratic nation-state with a commitment to gender equality. These can be seen in the approval of a democratic constitution in 1998 and the ratification of international agreements, like the Convention on the Elimination of all Forms of Discrimination in Albanian public administration. (Calloni 2002) One of the main gender concerns in Albania today seems

4 TDS Albanian Europe, internet link 2010, pp 12, 34, 15 
to be the missing link between putative and real equality in terms of access to employment, businesses, credit institutions, health care and social services. There are also questions about gender equality in civic participation and political decision-making. Albanian law prohibits gender discrimination and job segregation in public and private employment.
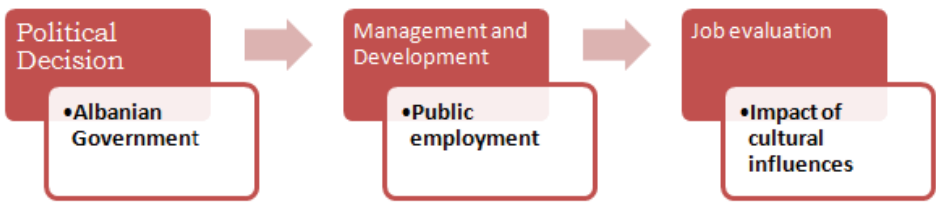

Graph 1: The heads of central and local government institutions, Source: Albanian BB for Albania, report 2011

In this study we are trying to analyze empirically, the impact of cultural, economical, prejudices factors, reforming in Albanian public administration, in the municipal bond market, like Balkan countries. Based on positive political theory and the benefit principle of taxation, benefit of social development in Balkan areas, it is proposed that states that adhere to best practice debt management policies transmit signals to the credit ratings, investment community and influences of prejudices. Balkan countries and Albanian government, on the other hand, should meet its obligations in a timely manner, resulting in lower debt costs. Although the field of entrepreneurship in Balkan is recognized as being of fundamental importance for Balkan economy, and many researchers throughout the world have turned their attention to it, there's, as yet, no agreement as to the research object in this scientific field. [4] [5], [6], [7]

\subsection{The economic dimension of regional cooperation}

Regional cooperation is essential for increasing prosperity and economic growth. Economic development is a key issue if the WBs countries are to make better, faster progress towards European integration. In many areas, such as trade, energy and transport, because of the limited size of each WBs country and the fragmentation of the economic space in the region, there is no other option but to embark on intense regional cooperation as the only realistic way forward. Enhanced regional cooperation in the economic field is just plain common sense.

Beyond the intra-regional challenges, the ultimate goal is to reconnect the WBs countries fully with all their neighbours, EU Member States and candidate countries alike.

\subsection{Albania administrative influences}

The Government of Albania has adopted a comprehensive policy reform program to strengthen Albania's weak institutional and governance capacity. This policy reform program is being supported by a Structural Adjustment Credit, which was approved by the Bank in June of 1999. Through regional cooperation, a business environment will be created in the WBs that will provide for foreign and national direct investments, that will create much needed jobs and that will encourage individual initiatives, and so add to an increase in the living standard of the whole population.
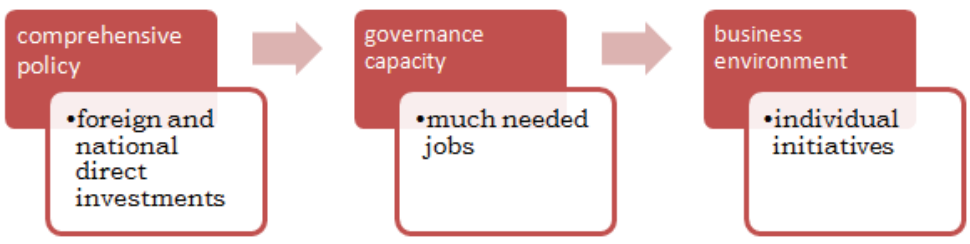

Graph 2: The heads of central and local government institutions, Source: European Communities, Brussels, Belgium), 1992

In the pursuit of these objectives the countries of the WBs can count on the support and the assistance of the EU. The idea of an economic space in the region is taking roots. In this context, some important results have been achieved in the 
WBs in the fields of free trade and infrastructure. The overall objective of the proposed Public Administration Reform Project is to provide required resources for technical assistance, training, goods and incremental operating costs that are needed to implement the Government's Institutional and Public Administration Reform agenda effectively.[8],[9],[10].

\section{Research Goal and data collected}

The Development Credit Agreement (DCA) states the objective of the project to be: The objective of the Project is to assist the Borrower to improve its capacity with regard to policy formulation and coordination, and administrative performance so as to create conditions that will encourage the Department of Public Administration of the Borrower to improve their service delivery.

\subsection{Albania's administrative system and public sector.}

At that time, Albania's administrative system was considered chaotic and ineffective. Its administrative culture - a combination of many influences - emphasized security over service delivery. The capacity of public administration was weak; the system, stemming from a party focused environment, was highly politicized. Corruption was pervasive in every facet of the public sector. Citizens feared public administration and did not trust it to provide even the most basic services in a fair or impartial way.

$\mathrm{H}$ 1.The Albanian - reforms aimed to create the managerial and professional nucleus required to lead any serious efforts to improve the accountability and performance of public institutions.

During the first years of the reform, the government focused on improving the legislative framework to ensure that its objectives could be achieved. By 1999, and prior to the approval of the credit under review by this ICR, the Government had identified and adopted a large number of measures which provided important institutional capacity to strengthen the public administration.

Supported by the Structural Adjustment Credit (SAC), and Public Expenditure Support Credit, the government undertook a number of pivotal actions which defined the framework of reform. Among them, Parliament revised the Civil Service Law in November 1999, and an independent Civil Service Commission (CSC) was created and staffed. (Bishop, E. B.1986) balances

H 2.Credit lines are not used as an 'extension' of a current account of the customer and can only bear debit

Credit lines are considered as a limit granted to a customer for use within a specific period of time. Micro businesses often use working capital to pay short term obligations as inventory or it can be also utilize for long term projects such as renovations or expansion. If working capital dips too low, a business risks running out of cash.

$\mathrm{H}$ 3: The small loans can be used as a fast cash option to caution the periods when cash flow is not available.

\subsection{Objectives and gathering data of this paper research.}

These results suggest a product of a pull-push process between the economic forces of the bond market on one hand and politics on the other, pulling the administrative function toward efficiency in the former and democratic values of responsiveness and transparency in the latter.

The problem lies in policies that respond to the bond market but virtually exclude any other community interest in policy making. It is recommended that openness in government and allowing taxpayers to understand government services are essential goals in ensuring responsible citizen oversight and providing taxpayers the opportunity to be less likely to propose restrictive initiatives or force dramatic political or management changes through the electoral process or bond referenda. (Bishop E. B.1986)

\subsection{Albania's administrative system and public sector.}

At that time, Albania's administrative system was considered chaotic and ineffective. Its administrative culture - a combination of many influences - emphasized security over service delivery. The capacity of public administration was weak; the system, stemming from a party focused environment, was highly politicized. Corruption was pervasive in every facet of the public sector. Citizens feared public administration and did not trust it to provide even the most basic services in a fair or impartial way. 


\section{The Process of Enlargement and Albania}

Candidate countries have to demonstrate that they will be able to play their part fully as members - something which requires wide support among their citizens, as well as political, legal and technical compliance with the EU's demanding standards and norms. Higgins, J. M 1983)

Countries wishing to join the EU can proceed from one stage of the process to the next, but only once all the conditions at each stage have been met. In this way, the prospect of accession acts as a powerful incentive to reform. The EU policy on enlargement ensures that the process is meticulously managed, so that accession brings benefits simultaneously to the EU and to the countries that join it.

- The mandate and the framework;

- Screening and monitoring;

- Closure of negotiations and Accession Treaty.

As the last of the Eastern European states to overthrow communism and with a legacy of international political isolation, Albania's experience of interaction with the EU is relatively short. In 1992 it entered into a Trade Agreement with the EU and in the intervening years has worked, with varying degrees of success, to implement domestic reforms in a bid to move towards EU standards. Albania is a potential candidate country for EU accession following the Thessaloniki European Council of June 2003. On 18 February 2008 the Council adopted a new European partnership with Albania. The SAA with the country was signed on 12 June 2006, after three years of negotiations. The SAA must be ratified by each EU Member State before coming into force, a process which could take some years, and it entered into force on 1 April 2009. In the meantime, an interim bilateral EU-Albania free trade agreement, which has been in operation since February 2003, will continue to function.

\subsection{Local government leadership and initiative in Albania}

Decentralization has given local governments the discretion and scope they need to take a lead role in responding to the challenges of economic down-turn degradation of the urban environment, and social hardship. They institute bold initiatives and innovative practices. Western European nations have put in place sophisticated frameworks to provide local governments with technical and financial assistance. The European Union supplements these national programs with coordinated assistance aimed at promoting economic development, assisting distressed localities and fostering social inclusion. Infrastructure is an important component of these programs.Anthony, $R . N$. and Dearden, J. Management Contol System, Irwin, Homewood, IL, 1990. Pg 147

Despite its location in an industrialized province Jerez's economy relies on wine production which, in recent years has been declining. Weak community participation, inadequate infrastructure, poor accessibility to regional resources and an unskilled labor force compounded the effects of massive job cuts in the wine industry (Higgins, J. M 1983)

With regard to economic development the plan focuses on the development of cultural tourism and the promotion of entrepreneurial activities.

Orientid keys of success are seven key factors:

- A dynamic local government leadership

- A coherent strategy acted upon with determination

- A healthy climate of cooperation with business

- Local government's investment initiatives to jumpstart the stagnant economy

- Creative use EU funds to implement local policy

- Efficient municipal administration

- Coherent links among urban planning, infrastructure and economic development

\subsection{Partnership between municipalities and NGOs}

Partnerships with municipalities has provided the best channel for the participation of communities in the organized delivery of public services and paved the way for the growing role of NGO' $s$ and CBO's in this sector in urban and rural areas and different regions of the world.

Albania, one of the smallest and poorest countries in Eastern Europe, has experienced a transition marked by sharp economic swings and periods of civil strife. The early phases of decentralization witnessed the transfer of political autonomy and limited administrative and fiscal authority, to local governments, inadequate legislation outlining 
central/local responsibilities, scarce financial resources and deficient infrastructure strained the capacity of local governments to mange urban services. In January 2000, the government promulgated a national Strategy for Decentralization and Local Autonomy which includes lows to strengthen the autonomy of local governments and increase their capacity to manage local infrastructure and services. (Bishop,E. B.1986)

Albanian government will be reality these points:

- A dynamic local government leadership

- A coherent strategy acted upon with determination

- A healthy climate of cooperation with business

- Local government's investment initiatives to jumpstart the stagnant economy

- Creative use EU funds to implement local policy

- Efficient municipal administration

- Coherent links among urban planning, infrastructure and economic developmement.

\subsubsection{The local government teams, NGO's and residents to formulate a development plan}

Supported by donor assistance and international and local NGO's the city initiated a community-based development strategy in the informal .The program brought together local government teams, NGO's and residents to formulate a development plan for the neighborhood define priorities for improvements and determine equitable cost-sharing formulas to finance infrastructure.

This partnership led to the upgrading of roads and electrical networks, the construction of community buildings and schools, improved public spaces and programs for youth. Clarifying the legal status of residential land and formalizing an urban plan resulted in the sufficient leveraging of community and house4hold resources to provide infrastructure and build new housing.

Finally, the engagement of senior government officials in the dissemination of project information secured commitment among communities and farmers.

\section{Conclusions and recomanded}

This is a highly significant feature of infrastructure programs and carries important implications for local development.

Sustained political pressure and the demonstrated capacity of municipalities to manage their responsibilities were the driving forces for local administrative and fiscal autonomy. Initial assessments suggested that decentralization did improve the quality of service delivery and foster a new, user oriented attitude, facilitating the transition from a centrally planned to a market economy.

The act for support of local investment committed the municipality to cover 50 percent of the cost of water, sewerage and power lines, 70 percent of the cost of roadbeds and sidewalks and 100 percent of the cost of drainage and street paving.

The cost sharing formula can be modulated to take into consideration issues of equity and cost burden. As an incentive to private rehabilitations of buildings, investors are granted a three year exemption from property taxes.

We recomanded these conclusions:

1. Introducing participatory planning and community-based development processes through neighborhood development committees and street representatives working in partnership with the city

2. Creating an enabling environment for private investment

3. Empowering citizens to pursue their own self improvement

4. promoting privatization of the housing a stock and fostering the development of micro- enterprises

5. Ensuring the sustainability of activities initiated

6. Promoting the reliability of successful initiatives.

\section{References}

Albania -Rural Water Supply and Sanitation Strategy 2003

Anthony, R. N. and Dearden, J. Management Contol System, Irwin, Homewood, IL, 1980.

Lorange, P. Scott Morton, M. F. and Ghoshal, S. Water Strategic Control West ST Paul, MN, 1986.

Newman E. H. Constructive Control: Design and Use of Control Systems, Prentice Hall, Englewood Cliffs, Nj.,1975. 
Higgins, J. M. Organizational Plicy and Starategic Management of Water, 2nd edn, Dryden New York,1983.

Hofer, C, W. and Schendel, D, Dtrategy Formulation: Analytical Concepts, West, St Paul, MN, 1983.

Industrial Performance Analysis, 1987-1988 edn, ICC Business Policy and Management Hidric Capacity,2nd edn Irwin, Homewood, IL,1985.

Glueck, W.F. and Jauch, L. R. Business Policy and Strategic Management, 4th, edn, McGraw-Hill, New york, 1984

Bishop,E. B. "ROCE as s Tool for Planning and Contol", Long Range Planning, 2,4, 1969, 80-7.

Tilles, S. "How to Evaluate Corporate Strategy", Harvard Business Review, 41,4,1963, 111-21.

.Hydric Management : Departament of the Environment, London 1990.

De Soto, Hermine; Egamberdi, Nilufar; Center for Economic and Social

Studies (CESS), 2001. Albania: Municipal Water and Sanitation Project - Social Assessment. Washington DC.

Government of Albania. 2003. The National Strategy for Socio-Economic

Development (NSSED).

Albania -Rural Water Supply and Sanitation Strategy 2009

Commission of the European Communities, "Council directive of 27 June 1985 on the assessment of the affects of certain public and private projects on the environment", in Official Journal of the European Communities, L175, pages 40-48.

" Towards sustainability-a European Community programme of policy and actions in relation to the environment and sustainable development" COM(92) 23 final- vol 11 ( Commission of the European Communities, Brussels, Belgium), 1992.

Leung, Hok Lin. Land Use Planning Made Plain Ronald Fruye \& Company: Kingston, Ontario, 1989.

Hermine; Egamberdi, Nilufar; Center for Economic and Social 